\title{
PENDIDIKAN LITERASI DIGITAL DI KALANGAN USIA MUDA DI KOTA BANDUNG
}

\author{
Hana Silvana, Cecep \\ Universitas Pendidikan Indonesia \\ hanasilva@upi.edu
}

\begin{abstract}
The phenomenon of the use of social media as an online media is increasingly massive in the use of this decade. Young people as the native millennial or digital generation are the biggest users in the use of social media today. Research on digital literacy is still rare, especially in Indonesia. The subjects of this study were young people aged 17-21 years that were active users of social media. This study uses a qualitative approach to the case study method. The informants who were used as research samples were 5 people and 1 key informant from media literacy experts. The findings obtained in this study indicate the importance of digital literacy programs that have a positive impact on knowledge, understanding and skills in using the media, especially social media which is now often used as a source of information by audiences, especially among young people. information on using mass media, especially social media used by young people so that there is awareness in using the media. In this education participants do not all have this expertise because this skill requires continuous and consistent training so that they can do it well. Therefore digital literacy education is a solution that can be done by the government and elements of society and academics who care about the progress of the nation.
\end{abstract}

Keywords: Digital literacy, Young Age, Digital Literacy Education

\begin{abstract}
Abstrak
Fenomena pengunaan media sosial sebagai media online semakin massive pada dekade ini. Kalangan muda sebagai generasi milenial atau digital native merupakan pengguna terbesar dalam penggunaan media sosial saat ini. Penelitian mengenai literasi digital masih jarang dilakukan terutama di Indonesia. Subyek penelitian ini adalah kalangan usia muda dengan rentang usia 1721 tahun yang merupakan pengguna aktif media sosial. Penelitian ini menggunakan pendekatan kualitatif dengan metode studi kasus. Informan yang dijadikan sampel penelitian sebanyak 5 orang dan 1 orang informan kunci dari pakar literasi media. Temuan yang diperoleh pada penelitian ini menunjukan pentingnya program literasi digital yang memberikan dampak positif bagi pengetahuan, pemahaman dan keterampilan dalam menggunakan media terutama media sosial yang saat ini sering dijadikan sumber informasi oleh khalayak terutama oleh kalangan yang berusia muda. Program ini memberikan kontribusi yang signifikan pada penyebaran informasi dalam menggunakan media massa terutama media sosial yang digunakan oleh kalangan usia muda sehingga ada kesadaran dalam menggunakan media. Pada pendidikan pelatihan (diklat) ini peserta belum semua mempunyai keahlian ini dikarenakan keahlian ini memerlukan latihan yang terus menerus dan konsisten sehingga mereka dapat melakukannya dengan baik. Oleh karena itu pendidikan literasi digital merupakan solusi yang dapat dilakukan oleh pemerintah dan elemen masyarakat dan civitas akademika yang peduli terhadap kemajuan bangsa.
\end{abstract}


Kata Kunci: Literasi Digital, Usia Muda, Pendidikan Literasi Digital

\section{A. PENDAhULUAN}

Pengguna media sosial di Indonesia sebanyak $85 \%$ terhubung ke sosial media facebook group (facebook, instagram, whatsapp messenger) yang merupakan jumlah terbesar. Menurut infografis APJII, sebanyak 65 juta aktif menggunakan facebook setiap hari dan $50 \%$ bergabung digrup facebook. Pengguna instagram sebanyak 45 juta setiap hari dan jika dirataratakan memposting 2 kali lebih banyak dari global average (APJII, 2017).

Pada tahun 2010 - 2014, dari sekitar 2 juta pasangan menikah, 15 persen di antaranya bercerai. Angka perceraian yang diputus pengadilan tinggi agama seluruh Indonesia tahun 2014 mencapai 382.231, naik sekitar 100.000 kasus dibandingkan dengan pada 2010 sebanyak 251.208 kasus. Permasalahan yang muncul terkait dengan penelitian ini perlu diantisipasi dengan menyelenggarakan pelatihan literasi media bagi kalangan muda. Menurut David Buchingham (2001) bahwa pendidikan media bertujuan untuk mengembangkan baik pemahaman kritis maupun partisipasi aktif, sehingga memampukan anak muda sebagai konsumen media membuat tafsiran dan penilaian berdasarkan informasi yang diperolehnya, selain itu memampukan anak muda untuk menjadi produser media dengan caranya sendiri sehingga menjadi partisipan yang berdaya di masyarakatnya. Pendidikan media adalah soal pengembangan kemampuan kritis dan kreatif anak muda.

Pelatihan literasi media diperlukan agar masyarakat memiliki sikap kritis dalam menyikapi setiap informasi dan interaksi yang ada. Masyarakat perlu di berikan edukasi berkenaan dengan aturan dan cara main yang digunakan ketika dia memanfaatkan sosial media dalam kehidupan sehari-hari. Validitas media harus ditelusuri dengan cara mencari informasi dari berbagai macam media. Tujuannya untuk pencarian apakah isi dari berita memiliki informasi yang berimbang atau tidak. Kebebasan pers dan didukung oleh teknologi komunikasi dengan internetnya memungkinkan masyarakat untuk memproduksi dan mengkonsumsi informasi. Informasi yang dapat diperoleh dapat dengan mudah tersedia di media social. Pengguna media social rata-rata pada kalangan anak muda dan remaja. Pemahaman akan dampak buruk literasi digital perlu ditekankan pada pengguna agar tidak terjadi hal-hal yang tidak diinginkan. Penelitian yang dilakukan oleh Pratiwi dan Pritanova, (2017), menyebutkan bahwa pemahaman literasi digital yang buruk akan berpengaruh pada psikologis anak dan remaja yang cenderung menghina orang lain, menimbulkan sikap iri terhadap orang lain, mengakibatkan depresi, terbawa arus suasana hati terhadap komentar negatif, serta terbiasa berbicara dengan bahasa kurang sopan.

Literasi media pada saat ini lebih menjurus pada penggunaan media sosial yang dapat lebih dispesifikasikan pada literasi digital yang merupakan turunan dari literasi media yang lebih luas. Literasi media meliputi televisi, film, media cetak. Sedangkan untuk kajian yang diteliti pada penelitian ini adalah mencakup penggunaan media sosial yang meliputi facebook, instagram, twitter, youtube, path dll. Menurut Kurniawati dan Baroroh, (2016) pengertian literasi media terdiri dari dua kata, yakni literasi dan media. Secara sederhana literasi dapat diartikan sebagai kemampuan membaca dan menulis atau dengan kata lain melek media aksara sedangkan media dapat diartikan sebagai suatu perantara baik dalam wujud benda, manusia, peristiwa, maka literasi digital dapat diartikan sebagai kemampuan untuk 
mencari, mempelajari, dan memanfaatkan berbagai sumber media dalam berbagai bentuk.

Pemahaman yang cukup mengenai dunia digital bagi kalangan anak muda dan keterbukaan informasi di media sosial yang memberikan dampak negatif penggunaan media sosial seringkali dialami oleh kalangan muda. Menurut Stefany dkk (2017) literasi media adalah kemampuan pengguna media sosial yang secara kritis dan kreatif dapat menyaring informasi yang beredar diberbagai media.

Setelah menelaah kebutuhan dan kekayaan keilmuan yang semakin berkembang, peneliti mencoba menggambarkan dan merumuskan permasalah, yaitu bagaimana program pendidikan dan pelatihan literasi digital pada usia muda dapat memberikan kemampuan literasi digital dalam penggunaan media sosial dikalangan muda di Kota Bandung.

\section{B. KAJIAN LITERATUR}

Media baru yang sekarang banyak digunakan oleh hampir semua lapisan masyarakat adalah sosial media. Media ini yang dikenal dengan istilah jejaring sosial, media ini diantaranya adalah facebook, twitter dan youtube. Di Indonesia pengguna facebook menempati peringkat ketiga dunia setelah Amerika Serikat. Sedangkan pengguna twitter di Indonesia peringkatnya tidak beda jauh dengan facebook. Sedangkan youtube adalah situs web video sharing (berbagi video) yang popular digunakan. Umumnya youtube berisi video klip, film, TV serta video yang sengaja dibuat serta diunggah dengan berbagai tujuan tertentu. Menurut Jones dan Hafner (2012) penggunaan sekelompok orang untuk menemukan data yang berguna and menyingkirkan data yang tidak berguna, disebut algoritma social atau filter social. Dengan berpartisipasi dalam media sosial (seperti facebook, twitter), contohnya, yang dibentuk oleh teman teman, kolega, dan orang orang yang kita hormati dan percayai, kita memiliki akses pada data yang dapat dianggap penting. Ada kalanya teman dan kontak kita mencari informasi di internet dan menemukan sampah yang tidak menarik, dan sejumlah potongan data yang patut dibagi. Sampah yang tidak menarik 'disaring', dan data yang menarik dan berguna disebarkan dengan memposting pada media sosial. Ketika kita masuk ke media sosial tersebut, kita dapat menyaring data berdasarkan rekomendasi dari teman kita.

Hal tersebut dapat kita lakukan ketika menyaring informasi yang dianggap perlu atau dibutuhkan oleh kita dan membuang informasi yang tidak perlu atau informasi sampah. Sebagai pengguna media, khalayak harus dapat memilahmilah informasi secara cerdas, sehingga tidak terjebak pada berita yang bersifat hoax atau berita bohong.

Perkembangan teknologi komunikasi mempengaruhi cara kita berinteraksi. Tekhnologi komunikasi melahirkan internet yang mempengaruh setiap bidang kehidupan manusia. Interaksi sosial dapat dengan mudah terjadi dengan bantuan koneksi internet. Perusahaan telekomunikasi menciptakan banyak fiture atau aplikasi untuk memudahkan berkomunikasi dengan adanya media sosial. Gencarnya informasi dan perkembanan teknologi patut di sikapi dengan bijak. Teknologi seperti dua sisi mata uang yang sama. Media sosial ini di satu sisi bisa berdampat positif di sisi lainnya berdampak negatif. Menurut Kurnia dkk (2018), Media sosial merupakan sebuah sarana komunikasi yang dapat digunakan sebagai tempat untuk mencari informasi (sumber informasi) dan dalam penggunaannya diperlukan keterampilan literasi media.

Penggunaan media sosial yang juga merupakan bagian dari media komunikasi 
dapat mempengaruhi terhadap kepribadian seseorang. Apabila pengguna tersebut tidak melakukan filtrasi ataupun memiliki kemampuan dalam literasi media yang mereka butuhkan. Bagi generasi muda atau kalangan muda hal ini dapat menimbulkan permasalahan-permasalahan yang tidak diharapkan. Oleh karena itu perlu kesadaran tersendiri dalam menyikapi hal tersebut.

Menurut Ryan T \& Xenos (2011), mengemukakan tiga tipe pengguna media sosial yaitu narcissm, shyness dan loneliness yaitu dengan ciri-ciri sebagai berikut: Narcissm, posting lebih sering dari pengguna lainnya, memamerkan hal-hal yang semestinya tidak perlu diunggah (posting) (superficial behavior), media sosial lebih banyak digunakan sebagai selfpromoting behavior (menawarkan diri sendiri); Shyness, kecemasan sosial tinggi, menggunakan media sosial lebih sering daripada pengguna yang lain (terlihat dari jumlah postingan), media sosial digunakan untuk mengatasi kecemasan mereka; Loneliness, cenderung memiliki sifat yang merasa lebih nyaman dengan hubungan on line antar sesama manusia, selalu merasa kesepian, penuh rasa cemas, media sosial dimanfaatkan untuk mencari siapa aja.

Usia muda atau remaja berasal dari kata latin yaitu adolesence yang berarti tumbuh atau tumbuh menjadi dewasa. Istilah adolesence mempunyai arti yang lebih luas lagi, yaitu mencakup kematangan mental, emosional sosial dan fisik. Usia remaja adalah masa peralihan dari kanak-kanak menuju dewasa yang dialaminya dalam tiga tingkatan yaitu usia pra remaja yaitu 10- 12 tahun, remaja awal usia 13 tahun - 16 tahun dan remaja akhir usia 17 - 21 tahun (Hurlock, 1992).

Dalam penelitian ini usia dibatasi pada usia 17 - 21 tahun. Faktor eksternal pada masa ini mempunyai pengaruh yang cukup besar termasuk pula daya tarik media, faktor-faktor kebutuhan terhadap media dan manfaat yang dirasakan dalam mengkonsumsi media. Tujuan dasar literasi media ialah mengajarkan pengguna media untuk menganalisis pesan yang disampaikan oleh media massa, mempertimbangkan tujuan komersil dan politik dibalik suatu citra atau pesan media, dan meneliti siapa yang bertanggungjawab atas pesan atau ide yang diimplikasikan oleh pesan atau citra itu.

Pada dasarnya media literacy merupakan kepedulian masyarakat terhadap efek negatif dari media massa. Seperti kita ketahui media massa mempunyai dua sisi mata pedang memberikan dampak positif dan negatif. Sisi negatif terkadang lebih banyak dari sisi positifnya. Diantaranya mengurangi privasi individu, meningkatkan potensi kriminal, dan juga menimbulkan overload dalam berkomunikasi. Dengan memahami literasi media, audience media massa dapat memberikan reaksi serta menilai sebuah pesan media dengan penuh kesadaran dan rasa tanggung jawab.

Sedangkan dalam mengevaluasi program kegiatan literasi media (literasi digital) ada 3 dimensi dalam mengukurnya, diantaranya adalah dimensi motivasi, dimensi pengetahuan, dan dimensi keterampilan. Ketiga dimensi ini merupakan evaluasi terhadap pertama, tingkat keberhasilan atau pengelolaan program. Kedua, tingkat keberhasilan literasi media di tengah peserta atau partisipan anggota. Digital Literacy atau keterampilan abad 21, tercakup dalam keterampilan belajar dan inovasi, berpikir kritis dalam pemecahan masalah, komunikasi dan keterampilan kolaborasi. Menurut Alkalai (2004) terdapat 5 jenis kemahiran yang tercakup dalam istilah umum digital literacy meliputi:

1. Photo - visual literacy adalah kemampuan untuk membaca dan menyimpulkan informasi dari visual;

2. Reproduksi literacy adalah kemampuan untuk menggunakan teknologi digital 
untuk menciptakan karya baru dari pekerjaan;

3. Percabangan literacy adalah kemampuan untuk berhasil menavigasi di media non-linear dari ruang digital;

4. Informasi literacy adalah kemampuan untuk mencari, menemukan, menilai dan mengevaluasi secara kritis informasi yang ditemukan di web;

5. Sosio-emosional literacy mengacu pada aspek-aspek sosial dan emosional hadir secara online, apakah itu mungkin melalui sosialisasi, dan berkolaborasi atau hanya mengkonsumsi konten.

Sementara itu, Douglas A.J. Belshaw dalam tesisnya What is 'Digital Literacy'? (2012) mengatakan bahwa ada delapan elemen esensial untuk mengembangkan literasi digital, yaitu sebagai berikut:

1. Kultural, yaitu pemahaman ragam konteks pengguna dunia digital;

2. Kognitif, yaitu daya pikir dalam menilai konten;

3. Konstruktif, yaitu reka cipta sesuatu yang ahli dan actual;

4. Komunikatif, yaitu memahami kinerja jejaring dan komunikasi di dunia digital;

5. Kepercayaan diri yang bertanggung jawab;

6. Kreatif, melakukan hal baru dengan cara baru;

7. Kritis dalam menyikapi konten; dan literasi digital sebagai kecakapan hidup; dan

8. Bertanggung jawab secara sosial.

Elemen tersebut di atas merupakan elemen dasar dalam pengembangan literasi digital. Dengan dilakukannya digital literasi maka diharapkan dapat lebih memahami dan dapat mempunyai kemampuan dalam hal kognitif, komunikatif. Mempunyai kemampaun dalam kreativitas, mempunyai kepercayaan diri dan mempunyai sikap kritis dalam mengkonsumsi media sehingga dapat menghindari berita bohong dan fake, sehingga informasi yang diterima melalui media sosial dapat dipertanggungjawabkan kebenarannya.

\section{METODOLOGI PENELITIAN}

Penggunaan metode ilmiah dalam suatu penelitian merupakan suatu tahapan atau langkah-langkah yang akan berpengaruh terhadap menentukan suatu keberhasilan dari suatu penelitian sehingga penelitian tersebut dapat dipertanggung jawabkan. Strategi yang digunakan dalam penelitian ini adalah single case study (studi kasus tunggal), yaitu sebuah desain kasus yang memberikan kesempatan untuk melakukan eksplorasi yang mendalam dari fenomena tertentu. Melalui penelitian deskriptif dengan strategi single case study, penelitian ini akan memberikan gambaran secara lengkap dan mengeksplorasi seacara mendalam bagaimana program pelatihan literasi media dapat memberikan pendidikan terhadap kalangan usia muda di Kota Bandung. Mementingkan ukuran jumlah informan yang representatif (populasi) untuk diwawancarai karena penelitian kualitatif tidak bisa digeneralisasikan. Pemilihan informan dengan metode purposif berarti mencari informan yang dapat memberikan informasi sebanyak-banyaknya pada hal yang berkaitan dengan permasalahan penelitian dan tujuan penelitian. Metode ini digunakan untuk mengetahui bagaimana proses pelatihan literasi media dapat memberikan pendidikan terhadap kalangan usia muda. Pada penelitian ini informan terdiri dari 5 orang kalangan usia muda. Adapun teknik pengumpulan data yang digunakan meliptui wawancara, dokumentasi dan studi pustaka.

Peneliti harus memiliki syarat dalam menentukan subjek utama penelitian agar lebih spesifik dan memudahkan dalam pemilihan informan tambahan. Pemilihan dari informan ini didasari oleh perwakilan usia yang termasuk kedalam kategori usia 
muda dan tempat tinggal yang mewakili wilayah di Kota Bandung.

Berikut daftar subyek utama (informan)

yang dijadikan sumber penelitian:

1. Kamaludin (KD, 20 tahun): asal Ujung berung;

2. Sri Rahayu (SR, 21 tahun): asal Gerlong Girang;

3. Senja Nur F (SN, 17 tahun): asal Antapani;

4. Agnes Devi S. (AD, 17 tahun): asal Bale Endah; dan

5. Yos Zania: (YZ, 18 Tahun): asal Kebonjati.

Sedangkan informan kunci dalam penelitian ini adalah Santi Indra Astuti (SIA, 48 Tahun) yang merupakan penggiat literasi digital di Jaringan Penggiat Literasi Digital yang juga merupakan dosen di Kota Bandung.

\section{HASIL DAN PEMBAHASAN}

Pelatihan literasi digital diperlukan agar masyarakat memiliki sikap kritis dalam menyingkapi setiap informasi dan interaksi yang ada. Masyarakat perlu di berikan edukasi berkenaan dengan aturan dan cara main yang digunakan ketika dia memanfaatkan sosial media dalam kehidupan sehari-hari. Validitas media harus di telusuri dengan cara mencari informasi dari berbagai macam media. Tujuannya untuk pencarian apakah isi dari berita memiliki informasi yang berimbang atau tidak. Kebebasan pers dan didukung oleh teknologi komunikasi dengan internetnya memungkinkan masyarakat untuk memproduksi dan mengkonsumsi informasi. Fenomena banyaknya berita hoax atau informasi sumir diperlukan kesadaran untuk memilah berita. Pada tahap inilah diperlukan media literasi untuk menjembatani kebutuhan akan informasi dan edukasi informasi yang sehat.

Program literasi media ini bertujuan untuk memberikan pengetahuan, pemahaman dan keterampilan kalangan usia muda dalam mengakses informasi yang disajiakan oleh media massa. Pada perkembangannya media massa mengalami peningkatan yang pesat terutama pada media sosial. Pengguna media sosial di Indonesia merupakan pengguna yang aktif dan termasuk ke dalam peringkat 3 besar di dunia dalam penggunaannya. Hal ini cukup mengkhawatirkan karena pengguna media sosial ini merupakan kalangan usia produktif dan lebih spesifiknya adalah kalangan usia muda yang berusia kisaran 17-21 tahun. Media sosial yang dikonsumsi oleh kalangan muda ini berupa facebook, twitter, instagram dan youtube. Selain itu juga beberapa media sosial yang digunakan berupa media yang dapat digunakan secara individual (chatting) maupun grup seperti line, whatsapp, hang out, we talk dan lain-lain. Penggunaan media sosial saat ini sangat masif, terutama pada kalangan usia produktif. Media ini digunakan mulai dari anak usia balita sampai usia manula. Lamanya penggunaan media sosial ini dalam sehari ratarata dimulai dari 2 sampai 7 jam dihabiskan untuk mengakses informasi yang disediakan oleh layanan informasi tersebut.

Literasi digital sebagai rangkaian gerakan melek media yang dirancang untuk meningkatkan kontrol individu terhadap media yang mereka gunakan untuk mengirim dan menerima pesan. Kata kunci dari penting nya media literasi yaitu bagaimana kita memiliki filter atau kontrol terhadap media yang bisa digunakan untuk pencarian informasi dan hiburan. Landasan hukum perlu di perkenalkan sebagai pengetahuan bahwa kegiatan media literasi di lindungi oleh undang undang dasar. Ruang lingkup dari media literasi antar lain literasi teknologi, literasi informasi, literasi tanggung jawab dan kompetensi. Pengetahun akan literasi tekhnologi dikarenakan sesuai dengan teori determinasi tekhnologi mengatakan bahwa masyarakat dalam kehidupannya mengikuti perkembangan teknologi. 
Setiap lahirnya teknologi baru mempengaruhi cara pencarian informasi dan benteraksi. Terdapat tiga elemen dan tujuan pentingnya pengetahuan media literasi di berikan kepada peserta pelatihan antara lain: Sebuah pemikiran kritis untuk mengembangkan penilaian mandiri terhadap media; Sebuah kesadaran akan dampak media pada individu dan masyarakat; dan pemahaman tentang kewajiban etika dan moral praktisi media.

Metode yang digunakan pada pelatihan ini berupa diskusi dengan pendekatan pedagogi. Diskusi yang dilakukan seperti membahas berita berisi konten pornografi, pornoaksi dan berita bohong (hoax), selain itu dari riset yang di dapat bersumber dari pengadilan agama. Tingkat perceraian yang terjadi di Kota Bandung banyak di sebabkan oleh social media (Darmawan dkk, 2017).

Berbagai macam permasalahan yang ditimbulkan oleh media sosial ada baiknya jika etika dan moral harus di sosialisasikan. Hal tersebut sesuai dengan elemen terakhir dari tujuan pendidikan literasi media yaitu tentang kewajiban etika dan moral praktisi media. Penggunaaan media gawai harus di sertai dengan aturan dan kesadaran akan media. Kesadaran akan dampak media pada individu serta masyarakat. Peserta pelatihan diberi treatment agar dapat membedakan dampak positif dan negatif dari informasi yang diperoleh di media sosial. Selain itu pula mereka diminta untuk mengkoleksi dan mengumpulkan apa saja yang dapat menghindari dan meminimalisir dampak negatif dari media tersebut. Berikutnya adalah pembahasan tentang kewajiban etika dan moral praktisi media tidak cukup dengan metode belajar tanya jawab. Maka penugasan pembuatan mind mapping serta mengangkat studi kasus yang sering ditemukan di lapangan diberikan kepada peserta pelatihan. Para peserta pelatihan dibentuk beberapa kelompok setiap kelompok membuat mind mapping tentang media literasi, media teknologi beserta manfaatnya. Sesi kedua pada tahap pertama dilanjutkan dengan penugasan mengangkap studi kasus yang ditemukan dikehidupan sehari hari dan menjelaskan latar belakang mengapa hal tersebut bisa terjadi. Setelah kerangka berpikir dirumuskan sesuai dengan hasil observasi pada pengalaman tiap peserta, mereka ditugaskan untuk mencari solusi terhadap permasalahan tersebut. Solusi terhadap permasalahan tersebut didasarkan pada kewajiban setiap pengguna media sosial untuk mematuhi nilai, norma dan etika yang berlaku. Landasan tentang etika sudah diberikan pada materi pengantar di awal pelatihan.

Terlihat perbedaan sebelum diberikan materi media literasi dan sesudahnya. Perbedaan dapat diukur dari beberapa solusi yang tiap kelompok kemukakan di depan kelas. Tahap dua dilakukan ketika materi pengantar literasi media telah dievaluasi. Setelah hasil pengukuran telah di dapatkan maka pemberian materi tahap kedua berupa. Materi berupa literasi media yang lebih dispesifikasikan pada literasi digital dan perkembangan teknologi diberikan oleh narasumber kedua. Materi yang diberikan merupakan pendalaman dari materi yang sebelumnya telah diberikan. Pada materi tahap kedua narasumber memberikan pengetahuan berkenaan dengan perkembangan informasi pada sosial media. Dapat disimpulkan bahwa informasi yang disajikan pada media sosial mengalami metamorphosis. Pada content pemberitaan mengalami variasi dengan setting yang memiliki banyak ragam. Narasumber memberikan konten penjelasan konten yang beragam dilatarbelakangi oleh jenis media yang mengalami perubahan secara cepat dan masif. Beda media sosial berbeda karakteristik dan tentu saja segmentasi aplikasi dan fitur yang di berikan. Treatment yang diberikan untuk mengukur pengetahuan peserta akan pendalaman materi lebih bervariasi. Jika sebelumnya evaluasi dilakukan hanya sebatas diskusi dan tanya jawab. Pada tahap kedua 
peserta pelatihan diberi tantangan yang lebih beragam. Peserta diberikan tugas untuk membuat kerangka berpikir berkaitan dengan materi yang telah diberikan. Setelah itu setiap kelompok yang telah dibentuk harus mampu menjelaskan di depan kelas. Pada tahap ini dapat dilihat hasil evaluasi bahwa peserta bukan saja bisa menjelaskan kerangka yang sudah di rumuskan tetapi menganalisis situasi yang diangkat dari studi kasus yang aktual terjadi.

Tantangan yang berbeda diberikan para peserta pelatihan jika dihadapkan dengan perkembangan teknologi komunikasi di tengah masyarakat. Beberapa media terkonvergensi harus di cari kelebihan dan kekurangannya. Para peserta pelatihan mencoba untuk mengelompokkan jenis media terkonvergen yang menyediakan informasi dan memfasilitasi interaksi sosial. Kemudian, mengkelompokkan jenis serta karakteristik dari media komunikasi. Menganalisis setiap jenis media dengan karakteristik kelebihan yang dimiliki. Kelebihan apa yang dapat di manfaatkan pada tiap jenis media yang berbeda.

Pemahaman peserta dievaluasi dengan cara dibentuk kelompok tanya jawab di dalam kelas. Perkembangan kognisi peserta bisa diukur satu persatu dari konsistensi kognitif yang mereka miliki melalui proses tanya jawab atau diskusi. Berbagai macam permasalahan yang ditimbulkan oleh media sosial ada baiknya jika etika dan moral harus di sosialisasikan. Hal tersebut sesuai dengan elemen terakhir dari tujuan pendididian literasi media yaitu tentang kewajiban etika dan moral praktisi media. Penggunaaan media gawai harus disertai dengan aturan dan kesadaran akan media.

Program literasi digital saat ini sedang digalakkan dan diperhatikan oleh pemerintah pada kurun tahun terakhir. Pemerintah secara umum sudah mencanangkan tentang literasi dengan berbagai aspek. Sejalan dengan yang diungkapkan oleh key informant (informan kunci) bahwa literasi media harus secara gencar dilakukan untuk mengantisipasi dampak negatif media massa yang tidak disadari sudah masuk dala segala lini kehidupan. Pengguna media sosial mempunyai tingkat yang tinggi terdapat pada generasi muda. Hal tersebut diungkapkan oleh key informant bahwa media sosial sudah masuk ke dalam semua aspek kehidupan, sehingga melek media sangat penting ada pada semua kalangan, dan sosialisasi terkait dengan dampak media dan antisipasinya perlu dilakukan baik oleh pemerintah maupun elemen masyarakat.

Sosialisasi yang dilakukan terhadap masyarakat luas merupakan tanggung jawab pemerintah dan kaum intelektual yang dapat memberikan edukasi dalam literasi media ini. Media massa sebagai medium yang mempunyai manfaat yang banyak juga mempunyai dampak negatif yang tidak sedikit. Upaya melek media ini harus dilakukan juga oleh unsur masyarakat yang nota bene mempunyai edukasi yang baik. Menurut (SIA),

\section{"Masyarakat perlu diberikan edukasi sehingga mereka dapat menyaring informasi yang baik dan mempunyai keahlian dalam memilah dan memilih informasi yang mereka butuhkan, maka dari itu diperlukan literasi media."}

Program yang perlu dilakukan oleh Pemerintah salah satunya adalah dengan memberikan keahlian dasar berupa keahlian dasar memutuskan pajangan pesan yang dipilih dari suatu media, mengidentifikasi dan memilih simbol-simbol, keahlian mengenali pola-pola, merangkai simbolsimbol sehingga dapat ditafsir atau dimaknai, keahlian untuk menghubungkan simbol dengan makna yang telah mereka miliki sebelumnya. Keahlian dasar ini harus dimiliki oleh khalayak pengguna media, 
sehingga mereka akan terhindar dari jebakan informasi yang belum tentu kebenarannya.

Hal lain yang dapat dilakukan adalah dengan cek dan ricek informasi yang diperoleh dengan sumber yang berbeda. Seperti yang diungkapkan oleh informan kunci adalah sebagai berikut:

"Dalam menerima informasi dari website baik berupa berita ataupun infotaiment, khalayak dalam mengkonsumsi media harus melakukan cek dan ricek terhadap informasi tersebut, sebelum menerima informasi tersebut dengan mencari sumber informasi lain yang terpercaya.Setelah dapat diterima kebenaran informasi itu, kemudian boleh dilakukan sharing informasi terhadap berita yang diterima." (SIA)

Peserta yang mengikuti pelatihan ini mempunyai pandangan yang positif terkait dengan kegiatan ini menyatakan bahwa ketika mengikuti pelatihan ini sangat menarik dan bermanfaat, terutama korelasinya dengan jurusan saya, ilmu komunikasi. Saya belajar bagaimana saya harus membuat literasi dalam dunia jurnalistik maupun dalam caption di media sosial sekalipun. (SN)

Materi pelatihan yang disampaikan juga membahas tentang hoax atau berita bohong yang sudah berkembang dengan sangat memprihatinkan. Peserta tertarik dengan materi ini karena dengan adanya materi tersebut peserta dapat mengetahui trik-trik apa yang harus dilakukan untuk terhindar dari jeratan berita bohong atau hoax tersebut. Seperti yang disampaikan oleh Informan (YZ) mengatakan bahwa:

"Saya tertarik dengan materi hoax (berita bohong) yang dipaparkan. Melihat dari berita-berita di media sosial yang begitu banyak dan tidak terkontrol, saya rasa materi yang disampaikan sangat pas untuk masalah hoax saat ini".

Pelatihan ini juga diharapkan membuat peserta pelatihan lebih peka akan literasi digital dan berita bohong saat ini. Peserta yang lain juga mengatakan bahwa:

"Pelatihan literasi media, merupakan edukasi yang baik untuk mengantisipasi kesimpangsiuran informasi." (SR).

Dengan informasi akan membentuk sebuah pemikiran, dan pemikiran akan membentuk sebuah keputusan, yang mana sebuah keputusan akan membentuk sebuah sikap. Maka betapa pentingnya kita untuk memiliki keterampilan dalam memilah informasi sebelum kita menyebarkan informasi kepada teman-teman atau keluarga kita atau di media sosial di Indonesia.

Materi yang diberikan pada pelatihan literasi digital inipun beragam. Dengan pemateri yang sesuai dengan kapasitas dan bidangnya dengan metode dan penyampaian yang berbeda-beda. Namun tetap, pada akhirnya mengacu pada penjelasan dari literasi media itu sendiri. Para peserta diberikan modul mengenai literasi media selama pematerian. Setelah diberikan pematerian, para peserta dibagi kelompok, untuk mendiskusikan tentang literasi media/fenomena tentang literasi media yang sedang terjadi. Kemudian di presentasikan untuk bertukar pikiran antara yang mempresentasikan dengan audience. Terjadi sebuah diskusi yang menarik. Juga mendapatkan pengalaman baru saat proses diskusi itu berlangsung. Pada penghujung acara, para peserta di beri angket mengenai pelatihan literasi media itu sendiri, dengan tujuan untuk mengetahui respon dari audience sendiri terkait pelatihan literasi digital.

Para peserta diharapkan dapat memahami pentingnya literasi media, untuk kemudian diaplikasikan dalam kehidupan sehari-hari. 
Tanggapan informan (KD) terkait pelatihan ini mengemukakan bahwa pelatihan literasi media harus "digeliatkan", mengingat pesatnya perkembangan teknologi informasi yang sebanding dengan perkembangan informasi itu sendiri.

Pelatihan literasi digital merupakan sarana untuk menyampaikan informasi terkait pengetahuan, pemahaman juga keterampilan dalam menggunakan media massa. Peserta pelatihan yang termasuk kategori usia muda yang mempunyai rentang usia 17-21 tahun, maka materi yang diberikannya pun terkait dengan media yang sering mereka gunakan dan dijadikan sumber informasi. Baik untuk kebutuhan tugas sekolah, rekreasi dan juga sekedar untuk eksistensi diri. Sejalan dengan yang disampaikan oleh McQuill (2003) dalam Yosal (2009) seseorang yang menggunakan media massa didorong oleh empat motif, yaitu informasi, identitas pribadi, integrasi dan interaksi sosial, sosial hiburan. Motif tersebut dipengaruhi juga oleh cara media massa mengemas sebuah informasi, sehingga informasi yang tidak bernilai pun dapat "tampak" bernilai jika dikemas dengan sedemikian rupa sehingga menarik minat audience untuk menerima informasi tersebut.

\section{E. SIMPULAN DAN SARAN}

Pendidikan literasi digital untuk usia muda menjadi hal yang penting dilakukan karena usia muda adalah kalangan yang paling rentan dalam mengkonsumsi media. Selain itu pula usia muda yang diharapkan sebagai agen perubahan untuk mengatasi berbagai problema masyarakat digital. Keahlian dasar menjadikan aspek yang harus dipunyai oleh kalangan usia muda, yang dalam pelatihan ini telah dimiliki oleh para peserta pelatihan. Keahlian lanjut juga diperlukan untuk memaknai pesan-pesan media yang lebih kompleks yang biasanya memiliki banyak lapisan-lapisan makna. Semua keahlian tersebut pada akhirnya menentukan tingkat media literate dari setiap individu. Pada pelatihan ini peserta belum semua mempunyai keahlian ini dikarenakan keahlian ini membutuhkan latihan yang terus menerus dan konsisten sehingga mereka dapat melakukannya dengan baik. Oleh karena itu pendidikan literasi media merupakan solusi yang dapat dilakukan oleh pemerintah dan elemen masyarakat dan civitas akademika yang peduli terhadap kemajuan bangsa.

\section{DAFTAR PUSTAKA}

APJII, (2017). Infografis Penetrasi \& Perilaku Pengguna Internet Indonesia 2017. Jakarta: Asosiasi Penyelenggara Jasa Internet Indonesia.

Buchingham, D. (2001). Digital Media Literacies: rethingking media education in the age of the Internet, Research in Comparatie and International Education, 2(1), 43 - 45.

Darmawan, C. Silvana, H. (2017). Media Literacy: The Effect Of Communications Media On Young Age Divorce In Bandung City. International Conference (IBRAFF): Bandung.

Darmawan, C. Silvana, H (2017) Laporan Penelitian: Pengaruh Media Komunikasi terhadap Perceraian Usia Muda. LPPM Universitas Pendidikan Indonesia.

Belshaw, D. (2012). What is' digital literacy'? A Pragmatic investigation (Doctoral dissertation, Durham University). http://etheses.dur.ac.uk/3446/1/Ed. D._thesis_(FINAL_TO_UPLOAD ).pdf.

Eshet, alkalai. (2004). The Overarching Element for Successful Tecnology Integratiton, Springer International Publishing Switzerland 2015 Wan Ng. 
New Digital Technology in Education DOI 10.1007/978-3319-05822-6).

Iriantara, Yosal. (2009). Literasi Media. Cetakan Pertama. Bandung: Simbiosa Rekatama Media.

Jones \& Hafner. (2012). Understanding Digital Literacies (A Practical Introduction). New York: Routledge.

Hurlock, E.B. (1992) Development Psychology: A Lifepan Approach (terjemahan oleh Istiwidayanti). Jakarta: Erlangga Gunarsa.

Kurnia, D, N dkk. (2018). Hubungan Pemanfaatan Media Sosial Instagram Dengan Kemampuan Literasi Media Di Upt Perpustakaan Itenas. Edulib. Vol. 8 (1).

Kurniawati, J dan Baroroh, S. (2016). Literasi Media Digital Mahasiswa Universitas Muhammadiyah Bengkulu. JKM, Vol. 8 (2).

Pratiwi, N dan Pritanova, N. (2017). Pengaruh Literasi Digital terhadap Psikologis Anak dan Remaja. Jurnal Semantik. Vol 6, (1). 11-24.

Ryan, T., \& Xenos, S. (2011). Who Use Face Book? An investigation into The Relationship between The Big Five, shyness, narcissm, loneliness, and Face Book usage. Computers in Human Behaviour, 27(5), 1658-1664.

Stefanny, S dkk. (2017). Literasi digital dan pembukaan diri: studi korelasi penggunaan media sosial pada pelajar remaja di Kota Medan. Sosiglobal. Vol. 2 (1). 10-31. 